\title{
announcements
}

\section{On the Move}

Professor F. Buchthal, Institute of Neurophysiology, Copenhagen, Denmark, to University Hospital (Rigshospitalet), Research Building, Copenhagen, from 1 September 1977.

Professor H. G. Schweiger, Max-Planck Institut für Zellbiologie, Wilhelmhaven, Germany, to Max-Planck Institut für Zellbiologie, Ladenburg, from 1 August 1977.

Dr J. Lawrence Fox, Associate Professor of Zoology, University of Texas at Austin, to Max-Planck Institut für Biochemie, Martinsried, Germany for one year sabbatical from 1 September 1977.

Dr B. P. Dash, Department of Geology, Imperial College of Science and Technology, University of London, to Chair of Applied Geophysics, University of Ife, Ife-Ife, Nigeria for two years from 1 September 1977.

Details of changes of department, sabbaticals, where leave will be taken and so on should be sent to On the Move; there is no charge for this service.

\section{Appointments}

Professor A. Lazenby, to Director of the Grassland Research Institute from 1 August 1977.

Dr R. J. Slater, to Director of Medical Programs for The National Multiple Sclerosis Society from 1 July this year.

\section{Awards}

Drs J. K. Burdett and M. Poliakoff are joint recipients of the Meldola Medal, awarded by the Royal Institute of Chemistry and Society of Maccabaeans for their work on laser chemistry and chemical effects of light.

The Actonian Prize of the Royal Institution has been awarded to Professor R. L. Wain, Professor of Agricultural Chemistry at Wye College, University of London and Honorary Director of the Agricultural Research Council Unit on Plant Growth substances and Systemic Fungicides, for his work on the chemical control of plant growth and the chemical basis of disease resistance in plants.

Dr F. Greaves, of the Imperial Cancer Research Fund has been awarded the Paul-Martini Prize 1977 (20,000 DM) for his work on a new diagnostic method for the specific proof of acute lymphoblastic leukaemia cells.

\section{Meetings}

14-16 September, 3rd National Quantum Electronics Conference, Southampton (G. C. Thomas, Department of Electronics, University of Southampton, Highfield, Southampton, UK).

16-17 September, Joint Radiological Meeting, Guildford (The British Institute of Radiology, 32 Welbeck Street, London (V1, UK).

19-23 September, Application of Microprocessors, Newcastle (The Institution of Electrical Engineers, Savoy Place, London WC2, UK).

\section{Person to Person}

A cooperative programme 'Species Pollution at World Scale' is trying to assess the real situation of the problem of introduced species. Botanists with experience in floristics are kindly requested to send the following information. (1) Place and area surveyed, (2) number of native species, (3) number of introduced species, including ephemerals and (4) a complete bibliographical reference for quotation, to $\mathrm{E}$. $\mathrm{H}$. Rapoport, Fundación Bariloche, c.c. 138, Bariloche 8400, Argentina. Collaborators will receive the printed map.

Exchange 4-bedroom furnished house in Montreal for similar in London area July 1978-August 1979. Car also considered. Contact D. Denhardt, 4338 West Hill Avenue, Montreal, Quebec H4B 2S9, Canada.

There will be no charge for this service. Send items (not more than 60 words) to Marcus Dobbs at the London office. The section will include exchanges of accommodation, personal announcements and scientific queries. We reserve the right to decline material submitted. No commercial transactions.

21 September, Modern Trends in Fluorescence Techniques, Guildford (D. Irish, Hon. Secretary, UV Group, c/o Pye Unicam Ltd, York Street, Cambridge, UK).

21-23 September, The Safe Use of Materials, Nottingham (R. $H$. Biddiulph, Borax Consolidated Ltd, Cox Lane, Chessington, UK).
22 September, Heterotechnologies for the Mail Service, London (The Institution of Mechanical Engineers, 1 Birdcage Walk, London, UK).

26 September, Surface Expression of Orebodies, Swansea (The Institution of Mining and Metallurgy, 44 Portland Place, London, UK).

25-27 September, Conference on Engineering for Health in Hot Countries, Loughborough (R. Steele, University of Technology, Loughborough, UK).

25 September-11 October, 2nd International Kimberlite Conference, Santa $\mathrm{Fe}$, New Mexico (Kimberlite Conference, Sylvia-K Inc., 5671 Blue Sage Drive, Littletown, Colorado 80123).

26-28 September, International Conference on Distributed Computer Control Systems, Birmingham, UK (The Institution of Electrical Engineers, Savoy Place, London, UK).

26-28 September, 1st German Solar Energy Forum, Hamburg (Congress Centrum Hamburg, Am Dammtor, PO Box 302360, D-2000 Hamburg 36, Germany).

26-29 September, The Ist BOC Priestly Conference on Heterogeneous Oxidation, Leeds (J. T. Gleave, Special Courses Division, Department of Adult Education and Extramural Studies, University of Leeds, Leeds, UK).

27-29 September, International Conference on Power Electronics-Power Semiconductors and their Applications, London (The Institution of Electrical Engineers, Savoy Place, London WC2, UK).

28 September, Applications of BroadBand Tuneable Lasers, London (The Institute of Physics, 47 Belgrave Square, London SW1, UK).

28-30 September, Symposium on Platelets: A Multidisciplinary Approach, Florence, Fondazione Internationale Menarini, Piazza del Carmine, 4-20121 Milan, Italy).

\section{Reports and Publications Other countries-June}

Annals of the South African Museum. Vol. 72 Part 12: The Validity of Malacoraja Stehmann, 1970 (Chondrichthyes, Batoidea, Rajidae) and Its Phylogenetic Significance. By P. Alexander Hulley and Matthias Stehmann. Pp. 227. New Records of Marine Crustacea Africa. By Brian Kensley. South African Museum, 1977.)

Town: South African Museum, Pecheries du Canada. Office des Recherches sur 16. (Ottawa: Monistère des Pêches et de l'Environnement, Service des Pêches et de la Mer. 1976.)

SRI. People at Work: Annual Report 1976. Pp. 32 Menlo Park, California: SRI, 1977.) [22 United States Department of the Interior: Geologica Survey. Bulletin 1397-B: Mineral Resources of the Laramie Peak Study Area, Albany and Converse Counties, Wyoming. By Kenneth Segerstrom and 